\title{
MEMBENTUK PRIBADI MULIA MELALUI PENDIDIKAN NILAI: Studi Di SD Muhammadiyah Bodon Yogyakarta
}

\author{
Oleh: Sudrajat \\ Pendidikan Sejarah FISE UNY
}

\begin{abstract}
Spread corruption, collution and nepotism and increase of drugs, criminality etc. on the other hand was one of moral collapse in our nation. This phenomena was standpoint from morality mozaik from our generation and must be solved to make our nations better. The eduation is one of the most useful to revamp our generation, and values education must be implemented in schools.

This research used of qualitative method to thoroughly find fact and phenomena which the researcher himself as the instrument. The researcher used in-depth interview, participatory observation, and documentation to collect the data. The validity data is acquired by triangulation, the longer observation, negative case analysis, and references to check and recheck. The researcher used interactive data analysis method by Miles and Huberman to analyze the data which includes: data reduction, data display and conclusion.

The result shows that the headmaster, teacher, and staff of Muhammadiyah Bodon of Elementary School have significant role in the implementation of values education. As a manager, the headmaster planed, organized and evaluated the program. The teachers took the role of values educator, model to values teaching, supervisor and evaluator to values education program. The values education programs in Muhammadiyah Bodon Elementary School was implemented by comprehensive models that was integrated in learning, extracurricular, and particular events. The values developed in that school were the values of religion, clean and beauty, discipline, politeness, and honesty. The impacts of values education on the performance of students of Muhammadiyah Bodon Elementary School was significant. This can be seen from their achievements in school cleaning competitions, religion competitions, "batik" contest, Javanese speech contest etc. The factors that encouraged the implementations of values education were: good capability of human resources, school facilities, some programs which were in line with values education, and the active role of the school elements. The factors that discouraged values education program were: few of teachers who did not appreciate to values education programs, parents who did not care with affective education to their children, and the environment did not care with the implementation of values education in Muhammadiyah Bodon Elementary School.
\end{abstract}

Key words: Values, education, Muhammadiyah 


\section{A. Latar Belakang}

Dalam beberapa dasawarsa terakhir ini terjadi kecenderungan baru di mana kesadaran akan nilai mulai tumbuh kembali. Kecenderungan ini terjadi secara global dan dapat digambarkan sebagai suatu titik balik dalam perkembangan peradaban manusia. Orang mulai berbicara tentang nilai, bahkan untuk bidang yang dianggap bebas nilai sekalipun seperti sains dan teknologi. Titik balik berikutnya yang menempatkan isu-isu tentang nilai sebagai fokus perhatian adalah semakin populernya kecerdasan emosional dan kecerdasan spiritual. Di Indonesia mulai berkembang pendidikan dan pengajaran yang mengintegrasikan ilmu pengetahuan dan teknologi dengan aspek keimanan dan ketaqwaan terhadap Tuhan Yang Maha Esa. Bersamaan dengan itu sekolah-sekolah berusaha menciptakan iklim yang kondusif bagi tumbuhnya kesadaran nilai, moral, dan keagamaan bagi peserta didiknya.

Pengembangan nilai, moral, dan keagamaan semakin disadari sebagai sebuah kebutuhan yang mendesak mengingat kecerdasan kognitif saja tidak menjamin keberhasilan seseorang dalam kehidupan. Oleh karena itu, membangun keseimbangan antara aspek kognitif, afektif, dan psikomotor secara berkesinambungan merupakan nilai pendidikan yang paling tinggi. Dalam pandangan Zamroni (2000: 81-82) pendidikan merupakan sebuah proses yang berkaitan dengan upaya untuk mengembangkan pada diri seseorang tiga aspek dalam kehidupaanya yakni pandangan hidup, sikap hidup, dan ketrampilan hidup. Pendidikan merupakan pembudayaan atau "enculturation" yaitu suatu proses untuk mentasbihkan seseorang agar mampu hidup dalam suatu budaya tertentu.

Pendidikan nilai diharapkan semakin memperdalam pemahaman siswa tentang nilai-nilai moral, etika, dan budaya sehingga akan membuat mereka mampu mengambil keputusan yang secara moral dapat dipertanggungjawabkan. Oleh karena itu sudah selayaknya apabila pendidikan nilai ditempatkan sebagai salah satu sarana pembudayaan dan pemanusiaan yang bermuara pada pembentukan sosok pribadi yang memiliki kemampuan intelektual dan moral yang seimbang sehingga terbentuklah masyarakat yang semakin manusiawi (Doni Koesoema, 2007: 116).

Marginalisasi aspek penilaian afektif baik oleh sekolah maupun masyarakat secara umum merupakan keprihatinan bersama. Para guru dan praktisi pendidikan masih beranggapan bahwa keberhasilan pendidikan diukur dari aspek kognitif saja, sebuah proses yang lebih menekankan pada hasil pendidikan serta pengabaian terhadap proses pendidikan itu sendiri. Lebih parah lagi, mata pelajaran yang menuntut penilaian afektif seperti pendidikan 
agama dan Pendidikan Kewarganegaraan (PKn) juga mengukur keberhasilan pembelajaran dalam ranah kognitif (Yani Maryani, 2010).

Kegagalan yang paling fatal adalah ketika produk didik tidak lagi memiliki kepekaan nurani yang didasarkan pada moralitas (sense of humanity). Padahal substansi pendidikan adalah memanusiakan manusia, menempatkan kemanusiaan pada derajat tertinggi dengan memaksimalkan karya dan karsa (Zaim Elmubarok, 2008: 29). Ketika pendidikan tidak peduli dengan kemanusiaan, secara faktual produk pendidikan berada pada titik yang sangat kritis. Kasus merebaknya video mesum oleh pelajar, perkelahian antar pelajar, mahasiswa, merupakan contoh kegagalan dunia pendidikan.

Refleksi perjalanan pendidikan kita hingga saat ini terkesan melebihkan unsur keilmuan secara duniawi dan melemahkan kadar spiritual sebagai pembentuk nilai atau moral dalam kepribadian para generasi muda. Seorang siswa dianggap berprestasi dan mendapat predikat pelajar teladan berdasarkan kepada nilai yang bagus mata pelajaran tertentu. Moralitas kemudian menjadi terabaikan dan dianggap sebagai sesuatu yang usang. Generasi bangsa menjadi pribadi yang meletakkan segala sesuatu tanpa berlandaskan nilai moral dan etika sosial kesantunan (Dimas Bagus Wiranata Kusuma, 2010). Apabila dibiarkan terus berlanjut, niscaya generasi muda akan hidup dalam budaya hedonistis yang hampa akan nilai-nilai luhur yang melekat dalam diri bangsa.

Tujuan pendidikan yang sejatinya adalah dalam rangka membentuk manusia seutuhnya berubah menjadi sekadar ladang bisnis dan industri yang melihat peserta didik dan wali murid sebagai konsumen pasar yang menjadi objek bagi barang produksinya. Hubungan guru dan murid menjadi hubungan antara pedagang dan pembeli, sebuah hubungan yang kering, gersang, takbermakna, suatu hubungan yang mendasarkan pada untung-rugi (Shobahussurur, 2010).

Kecenderungan orang tua yang sibuk bekerja di luar rumah, pertengkaran di dalam rumah tangga, perceraian, kekerasan dalam rumah tangga, dan lain-lain telah memberikan pengaruh yang signifikan terhadap proses pendidikan. Terlebih lagi berkembangnya anggapan bahwa hanya sekolahlah yang bertanggungjawab terhadap pendidikan anak-anak, sehingga orang tua menyerahkan sepenuhnya pendidikan anaknya kepada guru di sekolah. Anggapan tersebut tentu saja keliru, sebab pendidikan yang berlangsung di dalam keluarga bersifat asasi. Karena itulah orang tua merupakan pendidik pertama, utama, dan kodrati, dialah yang memberikan pengaruh dan warna kepribadian seorang anak (Hasbullah, 1999: 21).

Melemahnya fungsi keluarga sebagai lingkungan pendidikan menimbulkan kehampaan moral dalam perkembangan moral anak sehingga terjadi kelainan perilaku dalam bentuk kenakalan misalnya: perkelahian, penyalahggunaan narkotika dan obat-obat terlarang, dan lain-lain. Untuk itu 
diperlukan perubahan paradigma dalam proses pendidikan di mana diperlukan kerjasama yang sinergis antara sekolah, keluarga dan masyarakat, sebagaimana ditekankan oleh Epstein (Fullan, 1997: 255) sebagai berikut:

The way school care about children is reflected in the way schools are about the children in families. If educators view children simply as students, they are likely to see the family as separate from the school. That is, the family expected to do its job and leave the education of children to school. If educator view students as children they are likely to see both the family and the community as partners with the school in children education and development. Partners recognize their shared interest in and responsibilities for children and they work together to create better programs and opportunities for students.

Doni Koesoema (2007: 118) menggarisbawahi pentingnya jalinan relasional antar individu di dalam dunia pendidikan itu sendiri dengan lembaga lain seperti keluarga dan masyarakat. Jalinan ini sangat mempengaruhi proses pendidikan bagi anak sebab setelah sekolah, keluarga, dan lingkungan masyarakat merupakan tempat di mana anak tinggal dan melakukan aktivitas sosial. Oleh karenanya hubungan yang sinergis di antara sekolah, keluarga, dan masyarakat harus dibangun secara konstruktif.

Pendidikan juga tidak dapat dilepaskan dengan otonomisasi atau pembebasan serta pembentukan pola berpikir kritis sebagai penyiapan generasi muda untuk menjadi warga masyarakat. Hal ini sangat urgen mengingat otonomisasi dan pembentukan pola berfikir kritis merupakan salah satu pilar civil society yang didambakan bersama. Berkaitan dengan hal tersebut, Winch (2006: 6) menulis:

If education is largely concerned with the preparation of young for adult life then it is natural to suppose that it will be largely, but by no means exclusively, concerned with the development of autonomy, if the exercise of autonomy is a central feature of a worthwhile life for an adult in that society. It is natural to suppose that autonomy is something that we need to prepare for.

Upaya peningkatan moralitas bangsa melalui pendidikan sewajarnya dimulai sejak dini, yaitu pada masa anak-anak. Pada saat itu, anak membutuhkan bimbingan, arahan, nasihat, serta teladan dari orang tuanya, terutama dalam mengajarkan dan mempraktikkan nilai-nilai moralitas dalam kehidupan sehari-hari. Bersamaan dengan itu pula, masyarakat luas diharapkan dapat berpartisipasi secara aktif untuk mendukung upaya tersebut, agar benihbenih moralitas positif peserta tumbuh subur. Itulah yang sangat diharapkan 
agar benih yang ada di dalam jiwa peserta didik dapat tumbuh subur sesuai dengan iklim yang ada di sekitarnya (Sembiring, 2010).

SD Muhammadiyah Bodon yang terletak di Desa Jagalan Kecamatan Banguntapan Kabupaten Bantul Propinsi Daerah Istimewa Yogyakarta mempunyai kiprah dan peran yang penting untuk meningkatkan moralitas ke arah yang lebih baik. Dalam kaitan tersebut, maka SD Muhammadiyah Bodon melaksanakan penanaman nilai-nilai ke-Islaman serta nilai-nilai lainnya dalam semua kegiatan pendidikan. Nilai-nilai tersebut sangat urgent untuk diintroduksikan kepada peserta didik dengan harapan generasi muda Indonesia ke depan akan lebih baik kualitas moralnya. Hal ini juga perlu mendapatkan apresiasi sehingga usaha dan peran semua pihak dalam upaya peningkatan moralitas bangsa mendapatkan dukungan spiritual hingga dapat berhasil dengan baik.

\section{B. Kajian Pustaka}

Nilai berasal dari bahasa Inggris yaitu value yang diturunkan dari kata dalam bahasa Latin (valere) atau bahasa Perancis Kuno (valois) yang secara etimologis artinya berguna, mampu berdaya (Bertens, 2007: ). Nilai dapat diartikan sebagai sesuatu yang dianggap baik atau buruk tentang suatu hal, sedangkan arti denotatifnya antara lain dimaknai sebagai harga. Barry (1985: 4) mengatakan bahwa nilai merupakan suatu penilaian tentang harga. Sementara itu Salbot \& Fleskova (2010: 228) menyatakan bahwa nilai dipandang sebagai suatu substruktur dari kepribadian yang mempengaruhi tindakan dan pengambilan keputusan orang secara signifikan, membentuk karakteristik dan persepsi seseorang tentang dunia luar: orang, benda, fenomena dan peristiwa. Nilai merupakan bagian dari orang yang dihubungkan dengan struktur kognitif dari kepribadian, ia merupakan faktor yang berkaitan dengan proses pemahaman, tetapi ia juga dihubungkan dengan emosi.

Sementara itu, Erdem (Yildirim, 2009: 166) menulis bahwa “... values are ethical rules, basic beliefs, and standars explaining the rights and wrongs that guide behavior; they are life-related attitudes that shape the decisionmaking process and help to make an accurate assessment of beliefs". Nilai melekat dalam karakter seseorang dan tumbuh dalam lingkungan budaya tertentu yang mengarahkan sikap, pola pikir, maupun tingkah laku seseorang. Sementara itu, Hill (Stephenson, 1998: 3) menyatakan

When people speak of values they are usually referring to those beliefs held by individuals to which they attach special priority or worth, and by which they tend to order their lives. A value is, therefore, more than a belief; but it is also more than a feeling. 
Seseorang yang hidup tanpa nilai merupakan kehidupan yang tidak memiliki orientasi. Ia tidak mempunyai alasan yang memaksa untuk mengejar sesuatu kecuali sesuatu untuk memperoleh sense of direction atau nilai dalam hidup (Copp, 1995: 180). Nilai memberikan frame of reference kepada seseorang untuk berfikir, bersikap, dan bertindak. Ia lahir dari penyikapan dan penilaian atas atas sesuatu hal yang faktual. Sementara itu, Gordon Allport (Rohmat Mulyana, 2004: 9) menyatakan bahwa nilai adalah keyakinan yang membuat orang bertindak atas dasar pilihannya. Nilai terjadi pada wilayah psikologis yang disebut dengan keyakinan yang merupakan tempat tertinggi dari wilayah lainnya seperti hasrat, motif, sikap, keinginan dan kebutuhan. Oleh karena itu keputusan benar-salah, baik-buruk, indah-tidak indah pada wilayah ini merupakan hasil dari serentetan proses psikologis yang kemudian mengarahkan individu pada tindakan dan perbuatan yang sesuai dengan nilai pilihannya.

Sementara itu, Hans Jonas (Bertens, 2007: 139), menyatakan nilai adalah the addresses of a yes, sesuatu yang ditujukan dengan ya kita. Nilai merupakan sesuatu yang kita iyakan atau kita aminkan. Nilai selalu mempunyai konotasi positif, sebaliknya sesuatu yang kita jauhi, sesuatu yang membuat kita melarikan diri seperti penderitaan, penyakit atau kematian adalah lawan dari nilai, yaitu non-nilai atau disvalue. Bertens (2007: 141) menyebutkan tentang ciri-ciri nilai yaitu: pertama nilai berkaitan dengan subjek karena tanpa adanya subjek yang menilai, maka nilai tidak akan ada. Kedua nilai tampil dalam konteks praktis di mana subjek ingin membuat sesuatu, dan ketiga nilai menyangkut sifat-sifat yang ditambah oleh subjek pada sifat-sifat yang dimiliki oleh objek.

Kata moral berasal dari Bahasa Latin yaitu mos (jamak: mores) yang berarti juga: kebiasaan, adat. Secara etimologis kata moral berarti nilai-nilai dan norma-norma yang menjadi pegangan bagi seseorang atau suatu kelompok dalam mengatur tingkah lakunya (Bertens, 2007: 7). Dalam pengertian tersebut moral merupakan sistem tingkah laku yang dijustifikasi oleh masyarakat untuk dijadikan pedoman dalam bersikap dan bertingkah laku. Oleh karenanya moral merupakan standar tingkah laku yang dianggap baik, benar, dan adiluhung menurut kebudayaan masyarakat tertentu.

Sementara itu Bary (1985: 5) berpendapat ... So when we use the word moral, we refer to an action or person insofar as either is considered right or good. When we use the word immoral, we refer to an action or person insofar as either one considered wrong or bad. Jadi terminologi moral merujuk pada tindakan atau seseorang sepanjang dianggap baik atau benar, sedangkan kata immoral merujuk pada tindakan atau seseorang sepanjang ia dianggap salah atau jelek. 
Kata lain yang memiliki kesamaan makna dengan nilai dan moral adalah etika. Etika berasal dari Bahasa Yunani yaitu ethos yang mempunyai banyak arti yaitu: tempat tinggal yang biasa; padang rumput, kandang; kebiasaan, adat, akhlak, watak, perasaan, sikap, cara berfikir. Dalam bentuk jamak (ta etha) artinya adat kebiasaan (Bertens: 2007: 4). Sementara itu Taylor (1969: 8) mengemukakan bahwa moral merupakan perwujudan dari seperangkat standar dan aturan sosial yang membimbing manusia untuk berbuat di dalam suatu kebudayaan. Lebih jauh Taylor menyatakan:

... morality is a set of social rules and standars that guide the conduct of people in culture. It is one aspect of a culture's whole way of life, and has a special importance to every one who has been brought up within the frame work of that way of life. When morality is understood in this way we can see that it can be investigated on two different levels that of the individual and that of society.

Jadi menurut Taylor, moralitas merupakan seperangkat aturan dan standar sosial yang memandu tindakan seseorang di dalam kebudayaannya. Moralitas merupakan salah satu aspek dari sebuah kebudayaan sebagai keseluruhan cara hidup dan sangat penting bagi semua orang yang ingin dianggap sopan. Ketika moralitas dipahami dengan cara ini, kita dapat memandang perbedaan orang di dalam masyarakat tersebut.

\section{Nilai-nilai yang Ditanamkan}

\section{Nilai-nilai Keagamaan}

Nilai-nilai keagamaan yang dikembangkan oleh SD Muhammadiyah Bodon dapat dilihat dari kegiatan-kegiatan keagamaan yang dilaksanakan secara rutin yaitu kegiatan sholat berjama'ah, taddarus Al Qur'an, hafalan do'a sehari-hari, hafalan surat-surat pendek (HDSP). Hal ini ditujukan untuk membentuk jiwa seorang muslim yang tawadhu' serta membiasakan diri melaksanakan perintah agama secara permanen. Di samping itu sekolah juga membiasakan siswa untuk bersikap, berbuat, dan melakukan kebiasaan yang dicontohkan oleh Rasulullah Saw. Karena Rasulullah Saw. merupakan tauladan yang harus ditiru oleh semua umatnya. Bagi SD Muhammadiyah Bodon, akhlah Rasulullah SAW diharapkan dapat terwujud dalam kehidupan seharihari khususnya ketika berada di sekolah. Beberapa akhlak yang berusaha diaktualisasikan dalam kehidupan di sekolah antara lain:

1) Berjabat tangan dan mengucapkan salam yaitu assalamu'alaikum warahmatullah wabarakatuh apabila bertemu dengan orang lain: guru, teman atau orang lain yang dikenal. 
2) Mendahulukan kaki kanan apabila memasuki ruangan (kelas, guru, masjid) dan lain-lain, serta mendahulukan kaki kiri bila masuk ke kamar mandi.

3) Selalu memulai dengan berdoa bila akan mengerjakan sesuatu.

4) Duduk dan menggunakan tangan kanan apabila sedang makan.

5) Selalu mengerjakan ibadah sholat baik sholat dhuha pada waktu istirahat maupun sholat dhuhur ketika hendak pulan sekolah.

6) Membaca Al Qur'an setiap hari (sebelum jam 07.00 WIB), dan lainlain.

Dengan mengaktualisasikan hal-hal tersebut, maka tidak mengherankan apabila kultur Islami sangat kental di dalam lingkungan sekolah. Lebih jauh lagi SD Muhammadiyah Bodon juga mewajibkan setiap orang yang memasuki lingkungan sekolah untuk berpakaian Islami, khususnya bagi wanita untuk mengenakan jilbab. Anjuran tersebut dituliskan dalam spanduk yang ditempelkan di depan sekolah sehingga diharapkan warga sekolah dan masyarakat dapat mengindahkannya.

\section{Nilai Kebersihan dan Keindahan}

Kebersihan dan keindahan merupakan aspek yang sangat penting sebab lingkungan sekolah yang bersih dan indah akan memberikan dampak yang positif bagi kesehatan semua warga sekolah. Salah satu syarat utama dari keindahan adalah kebersihan dan kerapihan. SD Muhammadiyah Bodon mempunyai program untuk mewujudkan sekolah yang bersih dan sehat (clean and healthy school) yang implementasinya sering disingkat dengan aksi semutlis (sepuluh menit untuk lingkungan sekolah) yaitu kegiatan kelas membersihkan dan merapikan lingkungan sekolah pada pagi hari sebelum jam pelajaran dimulai. (Wawancara dengan ST). Kegiatan semutlis dilakukan secara bergiliran dari kelas 1 sampai kelas 6 dengan tugas pokok membersihkan lingkungan sekolah dan menyiram tanaman yang terlihat kering.

Program lainnya adalah piket siswa dengan jadwal yang telah diatur oleh guru kelas masing-masing. Petugas piket biasanya datang lebih awal yaitu pada kira-kira pukul 06. 20 WIB untuk membersihkan kelas masing-masing serta merapikan lingkungan di sekitar kelas. Area yang dikerjakan oleh siswa meliputi kelas, halaman, dan taman sekolah. Dengan dipandu oleh guru kelas masing-masing siswa yang bertugas sebagai piket menyapu kelas dan halaman serta merapikan tanaman. Dengan kegiatan tersebut maka SD Muhammadiyah Bodon selalu terlihat bersih, rapi, dan indah. Untuk membuktikan keterangan kepala sekolah peneliti melakukan observasi di beberapa kelas dan lingkungan sekolah yang memang selalu kelihatan bersih, rapi dan indah. 
Hal ini yang dilakukan oleh sekolah adalah membiasakan siswa untuk berperilaku bersih dan rapi misalnya: 1) membuang sampah pada tempat sampah, 2) mengembalikan alat yang dipakai ke tempat semula, 3) langsung memungut sampah apabila menemukan, dan lain-lain. Kegiatan-kegiatan tersebut dipantau dan dievaluasi secara berkelanjutan sehingga mempunyai kontribusi yang sangat positif bagi upaya pembentukan lingkungan sekolah yang bersih, rapi dan indah.

\section{Nilai Kedisiplinan}

Kedispilinan merupakan nilai yang amat penting karena ia dapat membantu kesuksesan seseorang. Sejak dini nilai kedisplinan ditekankan oleh SD Muhammadiyah Bodon dengan mengacu pada hal-hal yang kecil misalnya tidak boleh terlambat datang di sekolah, mengerjakan tugas sekolah, mengerjakan PR, lengkap dalam berpakaian, dan lain-lain.

Bagi SD Muhammadiyah Bodon kedisplinan mutlak harus ditegakkan, karena kedisplinan merupakan kunci untuk meraih kesuksesan. Di samping itu displin merupakan salah satu tuntunan dalam Islam. Oleh karenanya bagi warga sekolah kedisplinan merupakan nafas dalam kehidupan sehari-hari mulai pagi hari hingga siang hari. Dalam hal ini guru harus memberikan contoh yang baik dalam menegakkan kedisiplinan di sekolah sehingga guru datang di sekolah lebih awal dibandingkan siswa. Bagi guru SD Muhamadiyah Bodon datang ke sekolah pada jam 06. 20 WIB bukanlah pekerjaan yang berat karena dilakukan dengan jiwa ibadah yang penuh dengan keikhlasan. Sedangkan siswa datang ke sekolah pada jam 06. 30 WIB dan paling lambat 06.45 WIB. Hal ini sebenarnya sesuai dengan ajaran Islam yang menganjurkan umatnya untuk beraktivitas sejak pagi hari.

\section{Nilai Kesopanan}

Nilai kesopanan yang dikembangkan oleh SD Muhammadiyah Bodon mengacu kepada ajaran Islam dan budaya lokal, khususnya budaya Jawa yang selalu menempatkan unggah-ungguh sebagai sentral dalam membangun pola hubungan dan komunikasi antar sesama manusia. Nilai kesopanan ditekankan pada sikap seseorang dalam berbicara, bersikap, dan berbuat sesuai dengan status dan kedudukan masing-masing.

Seorang siswa harus berbicara dan bersikap sopan kepada guru karena guru merupakan orang yang lebih tua dan sebagai pengganti orang tua di sekolah. Nilai kesopanan terlihat dengan nyata ketika proses belajar mengajar berlangsung di kelas. Contoh: ketika seorang siswa akan keluar kelas untuk suatu keperluan maka ia harus meminta izin dari guru yang sedang mengajar.

\section{Nilai Kejujuran}


Kejujuran merupakan sebuah barang langka yang sangat sulit untuk ditemukan di belantara kehidupan kita sekarang ini. Ia menjadi lenyap seiring dengan perkembangan dan kemajuan zaman. Merebaknya korupsi, mark up proyek, perselingkuhan, dan lain-lain merupakan klimaks dari ketiadaan kejujuran di dalam diri individu. Menyadari akan hal ini maka SD Muhammadiyah Bodon menjadikan kejujuran sebagai sentral dalam pendidikan nilai.

Bagi warga SD Muhammadiyah Bodon kejujuran harus menjadi nafas dalam kehidupan sehari-hari baik di kalangan guru, siswa, maupun karyawan. Dengan aroma kejujuran yang kental maka dimungkinkan adanya modal sosial (social capital) yang kuat di dalam masyarakat. Beberapa nilai kejujuran yang tampak dalam proses pembelajaran antara lain:

1) Kejujuran dalam mengerjakan soal ujian

2) Kejujuran untuk mengakui kesalahan misalnya terlambat datang di sekolah, tidak membawa perlengkapan tertentu. Dalam hal ini siswa diminta untuk menulis sendiri di buku afektif.

3) Kejujuran dalam jual beli di kantin. Untuk menunjang hal ini SD Muhammadiyah Bodon telah mengintrodusir kantin kejujuran dimana siswa mengambil sendiri barang keperluannya dan membayar sendiri.

Kantin Kejujuran yang dikembangkan oleh SD Muhammadiyah Bodon menyediakan barang-barang keperluan sehari-hari untuk siswa dan guru seperti: makanan ringan, keperluan sekolah seperti: buku tulis, pensil, rautan, penghapus, dan lain-lain. Kantin kejujuran didirikan pada tahun 2008 dan sampai sekarang masih tetap eksis mengawal tindak kejujuran siswa-siswi SD Muhammadiyah Bodon.

Kantin ini tidak ditunggu oleh seorang guru atau petugas, tetapi ada seorang pengurus yang bertugas merapikan barang-barang dagangan dan sekaligus melakukan rekapitulasi jumlah pemasukan yang diperoleh. Namun dengan berbagai pertimbangan Kantin Kejujuran ini hanya diperuntukkan bagi SD Muhammadiyah Bodon yang berada di Unit I yang mencakup kelas V dan VI. Beberapa pertimbangan tersebut antara lain:

1) Banyaknya jumlah siswa SD Muhammadiyah Bodon sehingga ditakutkan akan terjadi kesemrawutan di kantin tersebut.

2) Siswa kelas I sampai IV dirasa belum memiliki tanggung jawab yang memadai sehingga kurang memahami konsep beli dan bayar sendiri.

3) Keterbatasan petugas, barang dagangan, dan tempat sehingga tidak memungkinkan untuk melayani semua siswa SD Muhammadiyah Bodon. 


\section{Pola Penanaman Nilai}

\section{Kegiatan prapembelajaran}

Kegiatan prapembelajaran merupakan kegiatan yang dilaksanakan sebelum jam pelajaran dimulai. Seperti sudah diuraikan di depan bahwa siswa SD Muhammadiyah Bodon datang ke sekolah pada jam 06. 20 WIB. Pada saat datang ke sekolah siswa berjajar masuk ke kelas masing-masing dengan bersalaman dengan guru dan mengucapkan salam (assalamu'alaikum warahmatullah wabarakatuh). Untuk selajutnya dari jam 06-20 sampai jam 07.00 WIB siswa melakukan kegiatan sebagai berikut:

a) Taddarus Al Qur'an

b) Belajar membaca Al Qur'an dengan metode Iqro

c) Menghafal surat-surat pendek dalam Al Qur'an (juz ke-30)

d) Menghafal doa-doa sehari-hari

e) Mengerjakan PR bagi yang belum mengerjakan

f) Melakukan kegiatan piket bagi yang sedang bertugas piket.

Dari uraian di atas tampak bahwa nuansa Islami sangat kental terasa lingkungan sekolah. Ketika peneliti melakukan observasi peneliti tidak mendengar suara lain kecuali suara siswa yang sedang taddarus Al Qur'an dan hafalan surat pendek serta doa harian. Untuk kelas III sampai kelas VI kegiatan taddarus ini dipimpin oleh ketua kelas masing-masing, sedangkan untuk kelas I dan II kegiatan dipandu oleh guru kelas dibantu guru lain karena mereka masih dalam taraf belajar membaca Al Qur'an dengan metode Iqro'. Hafalan doa dan surat-surat pendek kadang-kadang juga digunakan oleh guru sebagai sanksi bagi siswa yang melanggar peraturan sekolah misalnya terlambat datang ke sekolah, tidak lengkap, tidak mengucap salam, dan lain-lain. Dalam kegiatan prapembelajaran kadang-kadang guru kelas juga memberikan penanaman akan arti pentingnya nilai-nilai Islam dalam kehidupan sehari-hari untuk mewujudkan keberhasilan di dunia dan keselamatan di akhirat.

\section{Kegiatan pembelajaran}

Kegiatan pembelajaran di SD Muhammadiyah Bodon selalu diawali dengan ucapan salam dari guru. Untuk pelajaran PAI guru agama akan memulai pelajaran dengan membaca surat Al Fatihah secara bersama-sama. Tujuannya adalah untuk menanamkan kesadaran kepada siswa bahwa kegiatan belajar semata-mata hanya mengharap ridho dari Allah Swt. Dengan penanaman konsep yang demikian diharapkan siswa akan melakukan kegiatan belajar dengan jiwa yang ikhlas serta didasari oleh semangat ibadah sehingga motivasi mereka untuk belajar menjadi lebih tinggi. Harapan akhirnya adalah mereka akan memiliki prestasi belajar yang membanggakan, baik orang tua, guru, maupun sekolah secara umum. 
Guru-guru selain Pendidikan Agama Islam juga selalu mengawali kegiatan pembelajaran dengan menanamkan pengertian bahwa kebersihan, kejujuran, kepedulian kepada sesama merupakan sikap yang harus dikembangkan oleh siswa karena hal itu merupakan tuntunan Islam. Kemudian guru melanjutkan materi pembelajaran dengan menggunakan strategi pembelajaran yang telah dirancang sebelumnya. Dalam menyampaikan materi guru kadang-kadang mengaitkannya dengan nilai-nilai Islam dan budaya lokal yang luhur. Setelah selesai pembelajaran guru biasanya melakukan refleksi tentang materi yang diajarkannya dan mengaitkannya dengan nilai-nilai Islam. Untuk memberikan reward kepada siswa yang telah berprestasi baik dalam kognitif maupun afektif, misalnya jujur, menolong teman, dan lain-lain guru akan memberikan satu bintang. Namun apabila siswa melakukan pelanggaran, guru mencabut bintang yang telah diperoleh sebelumnya. Bintang-bintang ini kemudian akan diakumulasi selama satu bulan sehingga kemudian diketahui siapa siswa yang paling baik afektifnya pada satu bulan terakhir.

\section{Kegiatan di luar kelas}

Dalam mengimplementasikan pendidikan nilai SD Muhammadiyah Bodon tidak hanya terpusat pada kegiatan pembelajaran di kelas, tetapi juga memperhatikan aspek di luar kelas. Aspek luar kelas yang dimaksudkan di sini adalah kegiatan di halaman sekolah pada waktu istirahat, atau kegiatan olahraga pada saat pelajaran olahraga. Pada saat jam istirahat sekolah mewajibkan siswa melakukan shalat dhuha. Shalat dhuha dilakukan secara bersama-sama (berjama'ah) yang diawasi oleh guru sehingga kegiatan tersebut dapat berjalan dengan lancar dan tertib. Guru juga membimbing do'a setelah shalat dhuha bagi siswa kelas I dan II yang belum hafal.

Setelah selesai melaksanakan sholat dhuha biasanya siswa bermain di halaman atau makan. Pada saat istirahat guru akan mengawasi siswa serta membimbing mereka untuk berperilaku Islami, meskipun sedang bermain atau bersosialisasi dengan temannya. Guru akan mencatat siswa yang melakukan pelanggaran dan bila perlu memberikan sanksi kepada siswa yang berbuat mengganggu siswa lain atau tidak sesuai dengan tuntunan Islam. Hal ini penting mengingat perbuatan menyimpang apabila dibiarkan akan ditiru oleh siswa lainnya serta dikhawatirkan akan mengkristal menjadi karakter siswa. Dengan demikian hal sekecil apapun akan menjadi perhatian dari semua pamong sekolah baik guru, karyawan bahkan kepala sekolah.

\section{Kegiatan keagamaan}

Kegiatan keagamaan dilaksanakan dengan tujuan untuk mengembangkan sikap sosial siswa serta sebagai upaya menyebarkan syiar Islam bagi masyarakat di sekitar sekolah. Kegiatan-kegiatan yang dilakukan meliputi 
kegiatan harian maupun kegiatan pada waktu-waktu tertentu. Kegiatan tersebut dapat dijelaskan sebagai berikut:

1) Ceramah keagamaan (Pembinaan karakter siswa)

Kegiatan ini berupa inkulkasi nilai-nilai Islam dan nilai-nilai budaya luhur ke dalam diri siswa setelah selesai mengerjakan shalat Zhuhur. Kegiatan ini dilaksanakan selama kurang lebih 10 menit dimana guru secara bergiliran akan menyampaikan pesan-pesan dan nasihat-nasihat kepada siswa untuk melaksanakan ibadah serta berperilaku secara Islami. Latar belakang kegiatan ini dilaksanakan setelah sholat dhuhur adalah agar setelah sampai di rumah anakanak masih mengingat pesan dan nasihat yang disampaikan oleh guru. Harapan sekolah ketika di rumah anak-anak tetap akan berbuat dan berperilaku seperti ketika berada di sekolah.

2) Pesantren Ramadhan

Kegiatan Pesantren Ramadhan dilaksanakan pada akhir bulan Ramadhan dan rutin setiap tahun. Pada bulan Ramadhan jam pembelajaran memang tidak seperti biasanya karena kegiatan pembelajaran hanya dilakukan sampai shalat Zhuhur. Di samping itu jam pelajaran juga dikurangi dimana 1 jam pelajaran menjadi 25 menit. Materi pembelajaran juga lebih banyak disampaikan materi tentang agama khususnya ibadah-ibadah yang disunahkan selama menjalankan ibadah puasa seperti: shalat, membaca Al qur'an, dan lain-lain. Sekolah juga menghilangkan pelajaran yang bersifat fisik seperti olahraga, HW, upacara, dan pelajaran seni (KTK). Pada kegiatan pesantren Ramadhan siswa diberikan buku khusus yang berisi kegiatan rumah siswa selama bulan Ramadhan seperti kegiatan sholat tarawih, taddarus, shalat wajib, dan lain-lain. Kegiatan Pesantren Ramadhan sendiri dilaksanakan pada akhir bulan Ramadhan yaitu pada hari Sabtu-Minggu sebelum liburan Hari Raya Idul Fitri. Selama dua hari satu malam siswa kelas V dan VI berada di sekolah untuk dibimbing dan dididik agama. Kegiatan yang dilakukan antara lain praktik ibadah, tajwid, taddarus, dongeng nabi, buka puasa bersama, dan makan sahur bersama. Mereka juga akan diberi tugas antara lain membuat tulisan tentang kegiatan Ramadhan di rumahnya masing-masing. Untuk kelas I sampai IV biasanya akan diadakan kegiatan buka puasa bersama yang dilaksanakan bergiliran di masjid sekolah. Kelas I sampai IV belum diwajibkan mengikuti pesantren kilat dengan berbagai pertimbangan antara lain karena mereka masih terlalu anak-anak sehingga secara psikologis masih sulit berat meninggalkan rumah dan tidur di sekolah. 
3) Pembayaran ZIS (Zakat Infaq dan Sodakoh)

Kegiatan ini dilakukan dengan tujuan untuk melatih dan menumbuhkan jiwa sosial siswa khususnya dalam mengembangkan kepedulian siswa untuk berbagi dengan sesama. Untuk itu sekolah secara khusus mengedarkan surat pemberitahuan kepada wali siswa bahwa sekolah siap menampung dan menyalurkan zakat, infak dan sodakoh dari wali siswa. Sekolah juga akan membentuk panitia khusus yang bertugas mencatat dan mendistribusikan ZIS dari wali siswa kepada orang-orang yang berhak menerimanya. Khusus kepada siswa sekolah mewajibkan kepada mereka untuk membayarkan zakah fitrahnya di sekolah. Dengan kegiatan tersebut diharapkan siswa memperoleh pengalaman langsung bagaimana tata cara dan hukum zakat, infaq dan shodaqoh tersebut dalam syari'at Islam. Diharapkan mereka nantinya akan tumbuh menjadi manusia yang dermawan dan senantiasa menunaikan kewajibannya sebagai muslim yaitu membayar zakat.

4) Ibadah Qurban

Ibadah Qurban dilakukan pada saat hari raya Iedul Adha pada setiap tahun. Kegiatan ini ditujukan untuk memupuk jiwa ibadah siswa serta mempertebal kepedulian seorang muslim kepada saudarasaudaranya yang kurang mampu. Untuk melaksanakan qurban sekolah membentuk panitia khusus yang bertugas menghimpun iuran siswa dan sekaligus mendistribusikannya kepada golongan yang tidak mampu khususnya yang berada di sekitar sekolah. Biasanya sekolah menyebarkan edaran kepada wali siswa dan meminta mereka untuk menyalurkan hewan qurbannya di sekolah. Bagi siswa biasanya diminta untuk mengumpulkan infak selam sebulan guna membeli hewan qurban yang nantinya akan disembelih di sekolah. Sementara itu bagi guru yang mampu diminta untuk menyembelih hewan qurbannya di sekolah sehingga kegiatan ini dapat menyemarakkan suasana Hari Raya Idul Adha di sekolah tersebut dan menambah syiar Islam di sekitar sekolah.

5) Kegiatan Malam Taqorrub

Kegiatan ini diselenggarakan pada khusus bagi siswa kelas VI yang akan melaksanakan ujian nasional (UASBN). Tujuan dari kegiatan ini adalah untuk menumbuhkan kesadaran kepada siswa bahwa siswa memiliki kewajiban untuk berusaha semaksimal mungkin dalam ujian nanti dan menyerahkan hasilnya sepenuhnya kepada Allah Swt. Dalam kegiatan tersebut biasanya siswa akan diminta untuk bermalam di sekolah kemudian dipandu untuk melakukan penyadaran tingkat tinggi bagaimana kecilnya seorang manusia di 
hadapan Allah Swt. Siswa juga akan dipandu untuk melakukan shalat tahajud bersama-sama untuk memohon kepada Allah Swt. agar dikabulkan do'anya yaitu lulus dalam UASBN.

\section{E. Peran Guru Dalam Implementasi Pendidikan Nilai}

1) Guru sebagai pengajar nilai

Sebagai pengajar nilai-nilai Islam dan nilai-nilai moral, guru harus mempunyai pengetahuan yang memadai. Untuk kepentingan tersebut sekolah memberikan fasilitas berupa pengajian untuk guru dan karyawan yang dilaksanakan sebulan sekali tiap hari Minggu Wage. Dalam kesempatan tersebut sekolah mengundang ustadz dan pakar-pakar yang berkompeten di bidangnya. Selain di sekolah guru juga selalu mengikuti kegiatan-kegiatan di lingkungan atau tempat tinggalnya masing-masing. Karena guru SD Muhammadiyah Bodon merupakan aktivis Persyarikatan Muhammadiyah maka mereka selalu terlibat dalam kegiatan amar ma'ruf nahi mungkar seperti kegiatan pengajian, diklat, seminar dan lain-lain. Dalam kesempatan tersebut guru dapat menambah wawasan dan sekaligus meningkatkan pengetahuannya. Kegiatan lain yang dilakukan oleh guru untuk mendukung perannya sebagai pengajar pendidikan nilai adalah membaca buku-buku ke-Islaman. Kegiatan ini biasa dilakukan di perpustakaan sekolah atau juga dilakukan di sela-sela jam mengajar. Di rumah mereka juga selalu meluangkan waktunya untuk membaca buku.

2) Guru sebagai teladan atau sebagai model.

Dalam pendidikan nilai guru berperan juga sebagai teladan atau model yang bagi siswa-siswanya. Kepala sekolah selalu menekankan bahwa guru merupakan selebriti di sekolah sehinggga apa yang diucapkan, dilakukan dan pakaian yang dipakai oleh guru akan selalu menjadi pusat perhatian siswa. Oleh karenanya guru SD Muhammadiyah Bodon dituntut berpakaian dengan rapi dan Islami serta siap menjadi model atau teladan. Dengan demikian meskipun guru SD Muhammadiyah Bodon rata-rata masih berusia muda, namun secara psikologis mereka sangat dewasa serta santun dalam bersikap dan bertindak. Mereka hafal Al Qur'an khususnya surat-surat pendek, doa-doa sehari-hari, dan tuntunan Islam lainnya. Dengan jiwa yang sabar dan ikhlas mereka membimbing siswa-siswanya untuk berbicara, bersikap, bertindak dan bertingkah laku sesuai dengan tuntunan Islam.

Dalam kaitan dengan pemberian teladan ini, peneliti mencatat beberapa hal yang dilakukan oleh guru maupun karyawan SD Muhammadiyah Bodon yaitu:

a) Guru memberikan contoh langsung kepada siswa tentang apa yang disampaikannya dalam pembelajaran. Dengan pemberian contoh langsung ini siswa secara kongkrit dapat melaksanakan dan meniru 
apa yang dilakukan oleh guru. Misalnya ketika bertemu dengan siswa, guru lain, atau tamu sekolah guru menyapa terlebih dahulu dengan mengucapkan salam dan mengajak berjabat tangan. Dengan demikian secara otomatis orang yang diajak jabat tangan langsung akan menyambut dengan mengulurkan telapak tangannya serta membalas mengucapkan salam. Guru juga secara langsung memberikan contoh bagaimana ketika berada di masjid yaitu dengan duduk dan berdzikir. Bahkan ketika peneliti sedang berada di kelas IA guru ikut makan bersama-sama siswa untuk memberikan contoh langsung adab makan kepada siswa.

b) Guru juga memberikan contoh langsung dalam praktek ibadah. Dalam hal ini guru berwudhu bersama-sama dengan siswa, serta menjadi iman dalam kegiatan sholat berjama'ah. Guru SD Muhammadiyah Bodon juga selalu mengerjakan ibadah sholat Dhuha karena mereka dituntut untuk memberikan contoh bagaimana sholat dhuha itu dilaksanakan.

c) Guru memberikan contoh langsung kebiasaan-kebiasaan yang baik dan perlu dikembangkan oleh siswa, misalnya seorang guru yang lewat di halaman sekolah dan melihat ada sampah, secara refleks guru tersebut memungutnya dan membuangnya di tempat sampah. Guru juga menyiram tanaman di pot yang kekeringan, membersihkan lantai sekolah yang kotor, dan lain-lain. Pemberian contoh langsung ini memberikan dampak psikologis yang amat signifikan bagi siswa karena mereka akan termotivasi untuk mengikuti dan mencontoh tindakan tersebut. Guru juga menanamkan pengertian bahwa sikap-sikap tersebut semata-mata ditujukan dalam rangka ibadah untuk menggapai ridho dari Allah SWT. Dengan demikian siswa akan mengikuti dan mencontoh sikap guru dengan hati yang ikhlas tanpa beban dan atas suruhan siapapun.

3) Guru sebagai pengawas pelaksanaan pendidikan nilai.

Sebagai pengawas pelaksanaan pendidikan nilai guru SD Muhammadiyah Bodon harus sudah berada di sekolah pada jam 06. 30 WIB. Sesampainya di sekolah guru segera mempersiapkan kelas untuk kepentingan prapembelajaran yaitu kegiatan taddarus atau membaca Al Qur'an. Mereka juga harus menyambut kedatangan siswa untuk bersalaman dan mengucapkan salam. Sambil bersalaman dengan siswa biasanya guru akan mengecek ucapan salam (assalamu'alaikum), tugas rumah, dan perlengkapan siswa. Apabila siswa sudah benar dan lengkap mereka akan dipersilahkan untuk masuk ke kelas masing-masing. Namun apabila siswa kekurangan perlengkapan, atau 
terlambat datang ke sekolah, mereka akan mempersilahkan siswa untuk mencatat pelangaran yang dibuat pada hari itu di buku catatan afektif siswa.

4) Guru sebagai evaluator dari pendidikan nilai

Sebagai evaluator guru berperan sebagai hakim yang harus memutuskan apakah seorang siswa harus diberikan sanksi atau harus diapakan. Pada umumnya pelanggaran yang dilakukan oleh siswa rata-rata merupakan pelanggaran ringan misalnya terlambat datang ke sekolah, tidak lengkap pakaiannya, belum mengerjakan PR, curang waktu ujian, usil terhadap temannya, dan lain-lain. Untuk kesalahan dan pelanggaran ringan seperti itu bila dilakukan berkali-kali guru akan memberikan sanksi tertentu yang bersifat mendidik, misalnya berdiri di luar kelas untuk menghafal surat-surat Al Qur'an bagi siswa yang datang terlambat, mengerjakan PR di luar bagi yang belum mengerjakan PR dan lain-lain.

Untuk pelanggaran berat seperti misalnya mencuri barang milik temannya, berkelahi dengan temannya dan lain-lain maka sekolah akan memberikan sanksi yang agak berat yaitu siswa diberikan skorsing selama satu minggu. Dalam waktu satu minggu tersebut anak dilarang masuk sekolah dengan tujuan orang tua dapat membina langsung anaknya di rumah. Bagi siswa sanksi skorsing memberikan efek jera yang signifikan karena secara sosial ia dianggap sebagai anak nakal oleh teman-teman di sekolahnya. Bagi orang tua sanksi tersebut dapat dijadikan refleksi bagi keberhasilan pendidikan anaknya, merasakan betapa beratnya tugas mendidik anak tersebut.

Di samping guru, peran kepala sekolah dan karyawan juga sangat penting dalam menunjang keberhasilan pendidikan nilai. Dengan kapasitasnya, kepala sekolah SD Muhammadiyah Bodon menjadikan implementasi pendidikan nilai sebagai salah satu visi sekolah. Kepala sekolah juga merancang dan mengorganisasikan pendidikan nilai secara seksama. Mulai dari menentukan nilai-nilai apa yang hendak ditanamkan, membagi tugas guru dan mengevaluasi implementasi pendidikan nilai. Di samping itu karyawan juga mempunyai andil yang besar, karena karyawan berhadapan langsung dengan murid dan wali murid, maka keteladanan dari karyawan akan menumbuhkan iklim yang kondusif dalam sekolah. Oleh karenanya semua elemen sekolah mempunyai peran yang penting dalam implementasi pendidikan nilai di sekolah.

\section{F. Penutup}

Pendidikan merupakan salah satu sarana yang dapat dimanfaatkan sebagai jalan untuk memperbaiki kualitas sumber daya manusia Indonesia terutama kualitas sikap, nilai dan moralitasnya. Pendidikan nilai yang dilakukan secara komprehensif sebagai-mana dilaksanakan oleh SD Muhammadiyah Bodon memberikan pencerahan kepada akan harapan 
peningkatan kualitas moral bangsa Indonesia. Pendidikan nilai secara komprehensif merupakan alternative bagi kita untuk membawa perubahan mendasar dalam kehidupan berbangsa dan bernegara.

Dalam mengimplementasikan pendidikan nilai, SD Muhammadiyah Bodon menggunakan strategi penanaman nilai komprehensif yaitu melakukan kegiatan penanaman nilai-nilai melalui semua kegiatan pendidikan baik pada prapembelajaran, kegiatan pembelajaran, kegiatan luar kelas, dan kegiatan ekstrakurikuler. Semua komponen sekolah baik kepala sekolah, guru, wali murid, dan karyawan memegang peranan penting sesuai dengan kapasitas dan kewenangan masing-masing. Dengan pola pelaksanaan yang demikiran siswa SD Muhammadiyah Bodon tumbuh menjadi generasi yang Islami.

Pola implementasi pendidikan nilai di SD Muhammadiyah Bodon dapat dijadikan model bagi pelaksanaan pendidikan nilai di sekolah lain, khususnya sekolah-sekolah Islam. Sedangkan bagi sekolah umum, negeri maupun non yang dikelola oleh lembaga swasta non Islam dapat memodifikasi pola-pola pelaksanaan pendidikan nilai di SD Muhammadiyah Bodon untuk disesuaikan dengan visi dan misi lembaganya masing-masing.

\section{Daftar Pustaka}

Ali Muhtadi. (2006). Penanaman nilai-nilai agama Islam dalam pembentukan sikap dan perilaku siswa Sekolah Dasar Islam Terpadu Luqman AlHakim Yogyakarta. Jurnal Penelitian dan Evaluasi Pendidikan, 1, 5061.

Anwar Sutoyo. (2009). Pemahaman individu: Observasi, checklist, kuesioner \& sosiometri. Semarang: CV Widya Karya.

Barry, V. (1985). Applying ethics: A text with readings. California: Wadworth Publishing Company.

Basrowi \& Suwandi. (2008). Memahami penelitian kualitatif. Jakarta: Penerbit Rineka Cipta.

Bertens, K. (2007). Etika. Jakarta: Gramedia.

Castigliano, D., Van Deth, JW., Wolleb, G. (ed). (2008). The handbook of social capital. Oxford: Oxford University Press.

Copp, D. (2001). Morality, normativity, and society. New York: Oxford University Press.

Darmiyati Zuchdi. (2008). Humanisasi pendidikan: Menemukan kembali pendidikan yang manusiawi. Jakarta: Bumi Aksara.

Denzin, Norman K., \& Lincoln, Yvonna S. (eds). (1994). Handbook of qualitative research. London: Sage Publication.

Department of Education, Science and Training of Australian Government. (2005). National framework for values education in Australian schools. Canberra: Commonwealth of Australia. 
Depdiknas. Undang-undang nomor 20 tahun 2003 tentang sistem pendidikan nasional.

Dimas Bagus Wiranata Kusuma. (2010). Urgensi pendidikan berbasis spiritual. Tersedia dalam http://us.suarapembaca.detik.com/read/2010/05/03/094003/ 1349872/471/urgensi-pendidikan-berbasis-spiritual. Diunduh pada tanggal 15 Juni 2010.

Doni Koesoema A. (2007). Pendidikan karakter: strategi mendidik anak di zaman global. Jakarta: PT Gramedia Widiasarana Indonesia. . (2009). Pendidik karakter di zaman keblinger. Jakarta: PT Grasindo.

Driyarkara, N. (1980). Driyarkara tentang pendidikan (kumpulan karangan). Yogyakarta: Kanisius.

Elliot, Stephen N., et all. (2000). Educational psychology: Effective teaching, effective learning. New York: Mc Graw Hill Companies.

Erikson, E.H. (2010). Childhood and society (Terjemahan Helly Prajitno Soetjipto). Yogyakarta: Pustaka Pelajar. (Buku asli terbit tahun 1953).

Firdaus M. Yunus. (2007). Pendidikan berbasis realitas sosial: YB Mangunwijaya- Paulo Freire. Yogyakarta: Logung Pustaka.

Fullan, Michael. (ed.). (1997). The challenge of school change: A collection article. Illinois: Skylight Training and Publisher Inc.

Hasbullah. (1999). Dasar-dasar ilmu pendidikan. Jakarta: PT Raja Grafindo.

Kaswardi, EM. K., ed. (1993). Pendidikan nilai memasuki tahun 2000. Jakarta: Grasindo.

Kirschenbaum, H. (1995). 100 ways to enhance values and morality in schools and youth settings. Boston: Allyn and Bacon.

Krathwohl, David R., Bloom, Benjamin S., \& Masia Bertram B. (1964). Taxonomy of educational objectives: The classification of educational goals handbook II: Affective domain. London: Longman Group Ltd.

Kurotul Aeni \& Sudaryanto. (2005). Proses pendidikan budi pekerti di Taman Muda Majelis Ibu Pawiyatan Tamansiswa Yogyakarta, Jurnal Penelitian dan Evaluasi, 7, 23-39.

Lickona, T. (1991). Education for character: How our school can teach respect and responsibility. New York: Bantam Books.

Maanen, JV. (Ed). (1983), Qualitative methodology, London: Sage Publication.

Masri Singarimbun \& Sofien Effendi. (1983). Metode penelitian survey. Jakarta: LP3ES.

Mc. Nergney, Robert F. \& Herbert, Joanne M. (2001). Foundations of education: The challenge of professional practice. Boston: Allyn \& Bacon.

Miles, Matthew B., \& Huberman, A. Michael. (1984). Qualitative data analysis: A sourcebook of new methods. London: Sage Publication. 
Nurasmawi (2006), Pendidikan moral dalam rumah tangga di kota Pekan Baru: Studi kasus di Kecamatan Sukajadi dan Kecamatan Tampan. Tesis magister, tidak diterbitkan, Universitas Negeri Yogyakarta, Yogyakarta.

Ornstein, Allan C. \& Levine, Daniel U. (1989). Foundations of education. Dallas: Houghton Mifflin Company.

Reimer, Joseph., Paolitto, Diana Pritchard., \& Hersh, Richard H,. (1983). Promoting moral growth: from Piaget to Kohlberg. New York: Longman Inc.

Rohmat Mulyana. (2004). Mengartikulasi pendidikan nilai. Bandung: Alfabeta.

Salbot, V. \& Fleskova, M. (2010). Values orientation of university students and personal values related to the domain of education. The New Educational Review. 228-241.

Santo J.D. \& Cremers, A. (eds). (1995). Tahap perkembangan moral Lawrence Kohlberg. Yogyakarta: Kanisius.

Sembiring, S.S. (2010). Urgensi pendidikan dengan keteladanan. Tersedia dalam http://www.harianglobal.com/index.php?option=com_content \& view $=$ article $\& i d=1523 \% 3$ Aguru-menulis-urgensi-pendidikan-denganketeladanan\&Itemid $=53$. Diunduh pada tanggal 5 April 2010

Shobahussurur. (2010). Pendidikan nilai sebuah keharusan. Tersedia dalam http://www.mailarchive.com/fossei@yahoogroups.com/msg04648.html. Diunduh pada tanggal 8 Juni 2010.

Sri Rumini. (1993). Psikologi pendidikan. Yogyakarta: UPP IKIP Yogyakarta.

Sri Wening. (2007). Pembentukan karakter remaja awal melalui pendidikan nilai yang terkandung dalam pendidikan konsumen: Kajian evaluasi reflektif kurikulum SMP di Yogyakarta. Jurnal Penelitian dan Evaluasi Pendidikan, 10, 151-167.

Stephenson, Joan, et all. (1998). Values in education, London: Rouletdge.

Sugiyono. (2008). Metode penelitian pendidikan: Kuantitatif, kualitatif, $R \& D$. Bandung: Alfabeta.

Taylor, Paul W. (ed.). (1969). Problem of moral philosophy: An introduction to ethic. New York: Bantam Books.

Teuku Ramli Zakaria. (2009). Pendekatan-pendekatan pendidikan nilai dan implemen-tasi dalam pendidikan budi pekerti. Tersedia dalam http:/ /groups. yahoo.com/group/pakguruonline/message/131. Diunduh pada tanggal 27 Agustus 2009.

Thornberg, R. (2010). Values education as the daily fostering of school rules. Research in Education, 80, 52-62.

Winch, Christopher. (2006). Education, autonomy, and critical thinking. London: Routledge Taylor \& Francis Group.

Yani Maryani. (2010). Menelaah pendidikan nilai di sekolah. Tersedia dalam http://pendis.depag.go.id/lama/cfm/index.cfm?fuseaction=KajianBerita

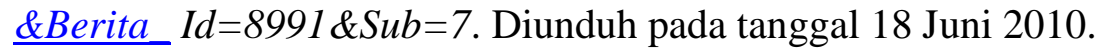


Yildirim, K. (2009). Values education experiences of Turkish class teachers: A phenomenological approach. Egitim Arastirmalari-Eurasian Journal of Educational Research, 35, 165-184.

Zaim Elmubarok. (2008). Membumikan pendidikan nilai. Bandung: Alfabeta.

Zamroni. (2000). Paradigma pendidikan masa depan. Yogyakarta: Bigraf Publishing.

Biodata Penulis: Sudrajat, M. Pd. menyelesaikan studi S1 pada jurusan Pendidikan Sejarah FPIPS IKIP Yogyakarta pada tahun 1999, sedangkan S2 dalam bidang Pendidikan IPS Universitas Negeri Yogyakarta diselesaikan pada tahun 2010. Menjadi dosen di Jurusan Pendidikan Sejarah sejak tahun 2006 dengan mengampu beberapa mata kuliah antara lain: Sejarah Eropa, Prasejarah Indonesia, Sejarah Indonesia Masa Hindhu-Budha, dan Sejarah Lokal. Beberapa karya ilmiahnya dipublikasikan beberapa jurnal antara lain: Istoria. 